\title{
PROFIT MOTIVATION AND MANAGEMENT ASSISTANCE IN COMMUNITY ECONOMIC DEVELOPMENT
}

\author{
Johin E. Oxendine* and Alvin N. Puryear $†$
}

In July r968 a community development corporation (CDC) in one of New York City's depressed minority communities initiated an economic development program which was designed to encourage local residents to initiate business ventures. After two years, it had provided financial and management assistance to over thirty minority entrepreneurs. The purpose of this paper is to present the findings of a study which examined the importance of profit motivation and management assistance in determining the success or failure of twelve of these businesses.

\section{I}

\section{The Assistance Program}

The CDC in this study is a non-profit, community-based corporation which supplemented its economic development activities with housing, community development, and employment projects. Its economic development program emphasized the establishment and expansion of business enterprises owned and operated by local residents. With respect to financial aid, the CDC gave loans of approximately $\$ 2$ million which, in turn, stimulated banks and private investors to provide a nearly equal amount of capital to these businesses.

The CDC felt that the creation and expansion of locally owned businesses was not a unique feature of community economic development. It believed that the more challenging task was to provide the means for insuring that local businesses would maintain their existence and grow into financially sound firms capable of generating economic returns for the community. While the $\mathrm{CDC}$ recognized that there was a need for management assistance, its approach in meeting this need differed from that of many other organizations. The dominant view in other assistance programs was that management assistance could best be accomplished through a system of volunteers, usually from outside the effected community. While recognizing that volunteers can play a very effective role in assisting local business development, the CDC questioned whether volunteers should be the primary instrument of assistance. As a consequence, the CDC decided not to use a "canned" program

\footnotetext{
* Consultant, Frye Consultants, Inc., San Francisco, California. Former Management Assistance Consultant to Bedford-Stuyvesant Restoration Corporation.

+ Associate Professor of Management, Bernard Baruch College of the City University of New York. Former Deputy Executive Director of Bedford-Stuyvesant Restoration Corporation.
} 
which might have worked for others, adopting, instead, a "contact man" system for its management assistance effort.

Under this system each businessman was designated the client of a CDC contact man who was given full responsibility for helping that client until a successful business operation was established. The contact man was expected to provide a wide range of services to the client. Initial assistance was often in the form of guidance to the client in his preparation of a request for funds. Typically, the contact man then assisted the client in negotiating with a bank, obtaining a business location, and selecting equipment and machinery. In effect, he provided all services which were needed to help an entrepreneur who was starting or expanding a business. Once the doors of the business were open, the contact man increased his efforts. It was then his responsibility to insure that the enterprise would be a success and add to the economic growth of the community. Obviously, the contact man, regardless of his skills, could not solve all problems and often had to go outside of the CDC to seek specialized skills. However, under this approach, even outside assistance, whether from volunteers or paid consultants, was secured under the direction of the contact man.

\section{II}

\section{The Determinants of Success}

In order to determine the ingredients necessary to insure a successful small business operation in a depressed community, we examined thirty-two firms assisted by the $\mathrm{CDC}$ and then selected twelve for an intensive study. Of the twelve, two were franchise operations, six were retail and service firms, and four were manufacturing companies. In the first category were a transmission franchise and a fried chicken franchise. The retail and service firms included a uniform guard service, a photo studio, a radio and television service store, an electronics store, a men's shoe store, and a moving company. The manufacturing concerns included a plastics manufacturer, a metal fabricator, a dress manufacturer, and a handbag manufacturer.

The twelve cases suggested that many factors influence the ultimate success or failure of a new business. In order to focus on the primary determinants of successful business development, we isolated five key factors which the case studies indicated were most important. The five were: (I) the technical competence or experience of the entrepreneur; (2) the capitalization of the business; (3) the amount of risk incurred by each entrepreneur; (4) the motivation of the entrepreneur; and (5) the ability and willingness of the entrepreneur to accept management assistance.

\section{A. Technical Competence: A Panacea}

At the beginning of its economic development program, the CDC believed that one key to successful community economic development was to assist individuals 
possessing technical competence or experience. The following factors supported this rationale: (x) the entrepreneur would know how to provide the products or services; (2) the entrepreneur would have a working knowledge of the industry's problems and practices; (3) the entrepreneur would know the sources of supply for raw materials and methods of distribution; and (4) the entrepreneur would be able to work out start-up problems in a shorter period of time. Consequently, the majority of the persons assisted by the CDC possessed a relatively high degree of technical competence. Many of these entrepreneurs had acquired their technical experience through employment in similar enterprises or through operating marginal businesses. All six of the service and retail trade entrepreneurs had some experience in their respective fields. Of the four manufacturers, only the plastics manufacturer lacked extensive experience before receiving $\mathrm{CDC}$ assistance.

While the CDC believed that technical competence was essential, it also made loans to a few persons who did not have experience in their new business fields. For example, it assisted the operators of the tranmission and fried chicken franchises because it felt that these were standardized operations and that franchisor management support greatly increased chances for success. Its loan to the plastics manufacturer was to continue the business that his cousin had started. In this instance, it felt that he would be able to hire persons possessing the necessary technical competence.

If the CDC's theory about technical competence was correct, one would expect that the businesses having owners with this competence would be more successful than those without. That is, the nine businesses in which the owners had technical experience would be successful, while those three in which the owners did not have experience would be less successful. Yet, the case examples did not allow us to draw such a conclusion about the value of technical experience. We saw that only four of the businesses in which the owners had technical competence were successful. These were the uniform guard service, the radio and t.v. service store, the metal fabricator, and the handbag manufacturer. At the same time, the other five-the photo studio, the electronics store, the men's shoe store, the moving company, and the dress manufacturer-were failures. Looking at the businesses in which the owners lacked technical proficiency, we found that two of the three-the transmission franchise and the plastics manufacturerwere failures, while the third-the fried chicken franchise-was entrenched solidly in success. Thus, while the CDC believed that technical competence was the key to creating successful businesses, the facts did not support this belief. Instead, the experiences of these entrepreneurs showed that technical competence was not a panacea, and that certain other ingredients would have to be present if success was to be achieved. In this regard, we examined the role of capital investment since many persons theorize that adequate capital is a necessary supplement to or substitute for technical competence. 


\section{B. Money: An Enigmatic Experience}

Studies of community economic development indicate that minority entrepreneurs can seldom marshal enough capital to start a business. Our analysis of owner's equity showed that twenty-seven of the thirty-two $C D C$ assisted businesses had owner's equity of less than $\$ 5,000$. More important, the average capital invested by the owners of the twenty-seven was $\$ 1,750$ or only 3.6 per cent of the average capital required of $\$ 48,000$. While three of the thirty-two businesses had owner's equity between $\$ 5,000$ and $\$ 15,000$, the owner's average capital contribution was $\$ 9,500$ or only 5.3 per cent of the average capital required of $\$ 179,500$. Finally, the CDC assisted two businesses which had capital contributions greater than $\$ 15,000$ and whose stockholders raised amounts which represented a relatively high sixteen and thirty-three per cent of the total capitalization required. Except for these two, however, it is significant that the entrepreneurs of the other thirty businesses were able to contribute less than five per cent of the total capitalization their businesses required.

It should come as no surprise to the reader that depressed minority communities have a severe shortage of internal capital. While one might expect outside capital to be available for ventures which show good economic promise, this has not been the case. In fact, the absence of external capital is as acute as the absence of internal capital. So the ghetto businessman must turn to the shylock for financing, or if he is lucky, to a community development corporation.

As indicated earlier, the CDC in our study had approximately $\$ 2$ million which it utilized with the owners' small equity investments to partially capitalize the businesses. At the same time, it leveraged its funds by pursuing bank participation on each venture. Consequently, its $\$ 2$ million coupled with the owner's investment and bank loans provided sufficient capital for the thirty-two businesses. The initial capital positions of the twelve case studies indicate the distribution and importance of this funding.

The two franchises had a total capitalization of $\$ 97,400, \$ 36,400$ of which came from the CDC, $\$ 57,500$ from other lending institutions and only $\$ 3,500$ from the owners. In both cases this was ample funding for the two operations. Yet one failed, while the other succeeded. The six retail and service firms also had adequate capitalization, although primarily because of assistance from the CDC and lending institutions. Of the total funding of $\$ 232,352$ for the six firms, the CDC provided $\$ 172,900$, lending institutions $\$ 51,252$, and the owners but $\$ 8,200$. In three casesthe uniform guard service, the photo studio, and the radio and t.v. service store-the CDC provided $\$ 89,500$ or ninety-six per cent of the total capitalization, a very high figure. Regardless of the "funding mix," the fact remains that each of the six was financed adequately, and that four of the six failed, while only two succeeded. Finally, a similar pattern existed with the manufacturing operations. While the lending institutions provided $\$_{1} 62,33^{8}$ to the four operations, 
the CDC was the primary financier, supplying $\$ 594,530$ or about seventy-five per cent of their total funds. Again two of the four were unsuccessful despite the fact that they received adequate funding from the $\mathrm{CDC}$ and the lending institutions.

Thus, although the CDC had limited funds, it was able to generate sufficient funds for all of the businesses it assisted. Yet of the twelve businesses, seven failed, including five of the nine in which the owners were also technically competent. While the CDC, the community, and the entrepreneurs believed that money could solve almost all problems, they learned that money and technical competence are not enough in themselves to guarantee success.

\section{Risk: The Unconscious Persuader}

In deciding among business alternatives in which to invest, it is important that funds not be given too freely, lest they defeat their primary purpose-to generate profits. Economists argue that the level of profits should be commensurate with the level of risk. In the absence of risk, one may no longer be concerned with profitability and funds may be used injudiciously for non-economic goals, thereby decreasing scarce pockets of capital. However, despite acceptance of this principle, the CDC did not include a risk factor in its financial assistance program. The evidence indicated clearly that most of its financial assistance was given consciously on a risk-free basis.

So far we have seen that the entrepreneurs of the six service and retail firms possessed a relatively high degree of technical competence and had sufficient funds to create profitable businesses. Furthermore, three of the four owners of manufacturing firms also had technical experience and sufficient funding. Finally, though the owners of the two franchises and one of the manufacturing companies did not possess this same degree of technical competence, they, too, received sufficient financial resources. Therefore, the question remains, Why did seven of twelve fail? Moreover, what accounts for five failures in cases where the entrepreneurs received sufficient financial assistance and had technical competence? Perhaps the failures of both the technically proficient and non-proficient can be explained by an absence of financial risk.

The case studies showed that only two of the nine entrepreneurs who had technical competence assumed any measurable amount of financial risk in starting their businesses. In this regard, it should be pointed out that all of the CDC loans were made to corporate entities, with the owners of the corporations having no legal obligations for the loan repayment. The best examples of absence of risk are found in the owners of the uniform guard service, the photo studio, and the radio and t.v. service store, all of whom not only received interest-free CDC loans, but in addition, had no bank financing for which they were liable personally. Equally important, they all had marketable skills which guaranteed them employment in the event that their businesses failed. 
A step removed from these with respect to degree of risk were the partners of the moving company, the handbag manufacturer, the dress manufacturer, and the metal fabricator. Although they were liable personally for bank loans, there was little risk since each of the four firms had collateralized loans secured by equipment, the value of which more than offset the owners' personal liabilities. Finally, only two of the technically proficient entrepreneurs were vulnerable in that their bank loans were not covered fully by capital assets. The owner of the electronics store had borrowed from a commercial bank to supplement his CDC loan. Though he had repaid some of this obligation before his store closed, the equipment which remained did not offset fully his liability to the bank. Similarly, the men's shoe store owner did not have sufficient assets to offset his $\$ 21,500$ bank loan. As a matter of fact, the store's fixtures and inventory were valued at only $\$ 5,000$, thereby placing a relatively large amount of risk on the owner.

Of the three entrepreneurs who did not possess technical competence at the outset, only one-the plastics manufacturer-was completely free of risk. While he received $\$ 29,500$ from lending institutions, it was more than offset by $\$ 100,000$ in plant machinery. The other two owners in this category-the transmission franchisee and the fried chicken franchisee-both had risk. Because the bank loan to the former was not offset fully by the value of the machinery and equipment remaining in his transmission shop, he stood to suffer from a business failure. The latter, because of heavy debt financing, was also in a very vulnerable position. Not only was he personally liable to lending institutions for $\$ 40,000$, but in addition, his chicken shop had little in capital assets as offsetting security. Thus, only three of the twelve owners faced a degree of risk likely to cause them to sustain personal financial losses.

In several of the cases, we found that lack of risk permitted or even encouraged the entrepreneurs to be unconcerned about the futures of their enterprises. Such cases illustrate clearly what happens to entrepreneurs who have sufficient money and technical competence, but who have nothing at stake in the event of failure. Had these entrepreneurs been liable for their investments to the extent of their personal and future assets, they might have exercised more protection for the assets of the business. Or they might have chosen not to go into business at all, in which case the risk factor would have served to select individuals committed totally to running successful ventures.

The case study revealed, however, several instances in which owners did not neglect their entrepreneurial duties even though they made small investments and had no personal risks. Do such cases indicate that in lieu of risk, entrepreneurs will be successful if, for example, they are willing to work long hours as did the handbag manufacturer and fried chicken franchisee? Certainly long hours are laudable, but do they explain success? Probably not, since it seems unreasonable to define risk-free, but successful, entrepreneurs in terms of hard work alone. 


\section{III}

\section{The Roles of Motivation and Management Assistance}

\section{A. Motivation: Mover of Men}

Motivation is an intangible quality which makes an individual want to succeed, no matter what the cost. One might view it as a creative dissatisfaction which forces a man not to accept his lot but to seek new levels of achievement. Regardless of a definition of motivation, it became clear from the twelve cases that it was a key ingredient in business success. Unanswered was how "motivation" is translated into successful business operations. "Wanting to succeed," "wanting to go into business," or "seeking levels of achievement" does not insure success. The evidence in the cases suggested that if the entrepreneur was to be successful, his motivation had to be directed toward business goals. And the most basic of all business goals is profitability. Therefore, essential for the successful development of a business are entrepreneurs characterizd by a high degree of profit motivation. The twelve cases illustrated that profit motivation was present in the operators of the successful ventures, and absent in the operators of the failures.

The contrast in the two franchisees, for example, was most evident in their respective views of the ultimate objectives of the businesses, and accounted largely for the success of the fried chicken franchise and the failure of the transmission franchise. While the owner of the former committed himself totally to making his business a financial success, the owner of the latter spent insufficient time at his enterprise, did not utilize the management advice he received, and demonstrated that he was not interested in making his enterprise financially successful. The case for profit motivation was also evident in the experiences of the six service and retail firms. Although all of these entrepreneurs possessed sufficient experience and capitalization, only two of the six were successful. As with the franchise operations, it was clear that an essential element in determining the success of each was their owners' high motivations toward the goal of profits. The importance of profit motivation was made clear again in the case studies of the manufacturers assisted by the CDC. The metal fabricator and the handbag manufacturer possessed a high degree of profit motivation, while the unsuccessful owners reached their goals by "being in business," not by showing a profit. The divergence between these two views is wide enough to show that the profitability goal was a key determinant of success.

Thus a significant difference between the two groups-the successful and the unsuccessful - was the level of their commitment to the goal of profitability. This was reflected in the entrepreneurs' willingness to put forth the effort necessary to guide their firms to profitable positions, regardless of other-often personal—considerations. The cases illustrated that while technical proficiency, money, and risks contributed toward success, they had to be supplemented by profit motivation. Yet, all of these were useless without a vehicle to give them proper direction. This vehicle was managerial skill. 


\section{B. Management: The Essential Ingredient}

In the twelve case studies we found that a variety of conditions existed with respect to each business and each entrepreneur. This was especially true in correlating success to technical ability, financing, and risk. Though all twelve firms were funded adequately, the degree of success of each was not related directly to the experience of the entrepreneur or the potentiality of a personal loss to him. In fact, the only consistent ingredient with respect to success was that the five successful entrepreneurs had a high degree of motivation toward achievement of profitability, while it was absent in the seven unsuccessful owners. Implicit in the cases was the notion that, in addition to profit motivation, the successful firms were also characterized by a pattern of good business management.

The CDC's experience showed that management may take one of two forms, enlightened or unenlightened. The unenlightened manager was incapable of giving overall direction and coordination to his business. Moreover, he was unable to see the necessity of supplementing his abilities with the skills needed to develop a profitable enterprise. Of even greater significance, the unsuccessful manager was not motivated sufficiently to even accept the management assistance provided through the CDC's "contact man" system. Thus, the unenlightened manager did not recognize the need to supplement his skills even when the assistance was available and given within an organized structure.

In this regard, an analysis of the twelve cases indicated clearly that the seven unsuccessful owners, in addition to lacking profit motivation, were also unenlightened. In looking at the management experiences of the five technically proficient owners who failed, one might have argued that their prior experiences should have prepared them to operate a business. This was not the case since their technical experiences could not overcome their management deficiencies. More important, these entrepreneurs also refused to accept any management assistance from the CDC. And the refusal to accept management advice does not limit itself to entrepreneurs who possess technical proficiency. Unfortunately, the owners of companies without this technical experience were also unreceptive. The transmission franchisee and the plastics manufacturer failed because they were deficient in both technical competence and management skills. In both cases the entrepreneurs did not accept the free management assistance made available by the CDC and others.

Despite such instances, there are cases-including the five successful firms in this study-where the CDC management assistance effort bore fruit. However, it should be recognized that in such cases, the owners were motivated to accept and use fully such assistance. Thus, the enlightened manager's capacity to give overall direction and coordination to the business resulted from his supplementing his management skills with the management assistance of an outsider who provides council.

If a businessman practices good management skills, or if he is willing to utilize 
fully a good management assistance program, it matters little that he might not possess the optimum amount of technical expertise. This fact is borne out in this study where the five owners who were motivated toward profit achievement did well regardless of their prior experiences. Of greater significance, these five cases also demonstrated that the entrepreneurs with this profit motivation were willing to accept, and, indeed, often sought CDC assistance in solving management problems.

\section{Conclusion}

Our analysis of the twelve case studies indicated that a variety of complex variables are important in determining how successful community development corporations will be in introducing economic development programs in this country's depressed areas. While one cannot say that these twelve examples are illustrative of all such minority business enterprises, it should be clear that-at the very leastthey do introduce several factors which must be considered relevant for successful community economic development.

The analysis showed that while technical experience is useful, it does not insure success. This point is especially pertinent when the experience is not related directly to the management aspects of business. Also apparent was the fact that adequate capital investment is a necessary ingredient to successful community economic development. However, the familiar cry for dollars must be offset with the knowledge that funds invested without adequate direction will bring no return. Even the widely accepted view that investment capital must be accompanied by a reasonable degree of risk is ot sacred. For as our study showed, risk does not guarantee that the entrepreneur will direct himself toward the business goal of increased profits. Finally, at least two other ingredients must be present if the CDC is to promote successful economic development programs. First, the entrepreneur must have a high degree of profit motivation. That is, he must see profits, and not "going into business," as his primary goal. Second, good management is essential. However, because most businessmen assisted by CDC's do not possess management backgrounds and training, they must be exposed to a good program of management assistance. We have seen that the profit motivated entrepreneur will avail himself of such management assistance. 